\title{
IMPLEMENTING OF STRUCTURAL ANALYTICAL SYNTHETIC (SAS) METHODS TO IMPROVE THE ABILITY OF EARLY READING OF ELEMENTARY SCHOOL STUDENTS
}

\author{
Neni Hermita ${ }^{1}$, Astri Widyanthi ${ }^{2}$, Otang Kurniaman ${ }^{1}$, Gustimal Witri ${ }^{1}$ \\ ${ }^{1}$ Universitas Riau, Pekanbaru, Indonesia \\ ${ }^{2}$ SDN 170 Pekanbaru \\ neni.hermita@lecturer.unri.ac.id, awidyanthi@gmail.com, otang.kurniaman@lecturer.unri.ac.id, \\ gustimal.witri@lecturer.unri.ac.id
}

\begin{abstract}
This research is motivated by the problem of the low ability to read the beginning of students, so that the SAS method is applied so that it can help students in the success of reading the beginning. The purpose of this study was to determine the differences in pretest and posttest by applying structural analytical synthetic (SAS) in reading the beginning of elementary school students and to determine the increase in pretest and posttest in reading the beginning of students. This type of research is a pre-experimental type of pretest-posttest one group design, which is an experiment that is only carried out in only one group, without comparison. This study was conducted in class 1 with 34 students. Based on the results of the study it was found that the average reading ability before being treated (pretest) was 51.77 while the average reading ability after treatment (posttest) was 88.41 and the average value of gain normality was 0.76 which including the high category and the results of hypothesis testing using t-test with $t_{\text {count }}=51.080$ and $t_{\text {table }}=2.0345$ can be concluded $t_{\text {count }}>t_{\text {table }}$, then reject $H_{0}$ means significant. This means that there is an increase in initial reading in class I students who are significant between before (pretest) and after (posttest) applying the Structural Analytical Synthetic (SAS) method.
\end{abstract}

Keywords: SAS method, read beginning, elementary school

\section{IMPLEMENTASI METODE STRUKTURAL ANALITIK SINTETIK (SAS) UNTUK MENINGKATKAN KEMAMPUAN MEMBACA PERMULAAN SISWA SD}

\begin{abstract}
ABSTRAK
Penelitian ini dilatar belakangi oleh permasalahan rendahnya kemampuan membaca permulaan siswa, sehingga diterapkan metode SAS supaya dapat membantu siswa dalam keberhasilan membaca permulaan. Tujuan penelitian ini adalah untuk mengetahui perbedaan pretest dan posttest dengan menerapkan metode struktural analitik sintetik (SAS) dalam membaca permulaan siswa kelas I SD dan untuk mengetahui peningkatan pretest dan posttest dalam membaca permulaan siswa. Jenis penelitian ini adalah jenis pretest-posttest one group design pra-eksperimen, merupakan eksperimen yang hanya dilakukan hanya pada satu kelompok, tanpa perbandingan. Penelitian ini dilakukan di kelas 1 dengan 34 siswa. Berdasarkan hasil penelitian ditemukan bahwa nilai rata-rata kemampuan membaca sebelum diberi perlakuan (pretest) adalah 51.77 sementara nilai rata-rata kemampuan membaca sesudah perlakuan (posttest) adalah 88.41 dan nilai rata-rata normalitas gain adalah 0.76 yang termasuk kategori tinggi dan hasil pengujian hipotesis menggunakan uji-t dengan $\mathrm{t}_{\text {hitung }}=51.080$ dan $\mathrm{t}_{\text {tabel }}=2.0345$ dapat disimpulkan $\mathrm{t}_{\text {hitung }}>\mathrm{t}_{\text {tabel}}$, maka tolak $\mathrm{H}_{0}$ berarti signifikan. Ini berarti terdapat peningkatan membaca permulaan pada siswa kelas I yang signifikan antara sebelum (pretest) dan sesudah (posttest) menerapkan metode Struktural Analitik Sintetik (SAS).
\end{abstract}

Kata Kunci: metode SAS, membaca permulaan, sekolah dasar

\begin{tabular}{|c|c|c|}
\hline Submitted & Accepted & Published \\
\hline 31 November 2019 & 21 Januari 2020 & 30 Januari 2020 \\
\hline
\end{tabular}

\begin{tabular}{|l|c|c|c|}
\hline Citation & $:$ & $\begin{array}{r}\text { Hermita, N., Widyanthi, A., Kurniaman, O., \& Witri, G. (2020). Implementing Of Structural Analytical Synthetic (SAS) } \\
\text { Methods To Improve The Ability Of Early Reading Of Elementary School Students. Jurnal PAJAR (Pendidikan } \\
\text { dan Pengajaran), 4(1), 280-288. DOI : http://dx.doi.org/10.33578/pjr.v4i1.7942. }\end{array}$ \\
\hline
\end{tabular}

\section{PENDAHULUAN}

Kemampuan membaca dan menulis di tingkat sekolah dasar adalah bagian dari keterampilan berbahasa. Bahasa adalah sarana untuk memperoleh ilmu dan sekaligus bagian dari budaya, serta sarana berkomunikasi. Kemampuan membaca menjadi dasar yang utama tidak saja 
bagi pengajaran bahasa Indonesia sendiri, akan tetapi juga bagi pengajaran mata pelajaran lain, oleh karena itu, membaca harus diupayakan semaksimal mungkin agar kelak anak tidak mengalami kesulitan dalam membaca. Siswa mengenal membaca secara bertahap, pengenalan itu dimulai huruf demi huruf yang kemudian dirangkai menjadi kata atau dari kalimat sederhana, kata-kata, suku-suku, dan baru kemudian tiap-tiap huruf. membaca adalah suatu proses yang dilakukan serta dipergunakan oleh pembaca untuk memperoleh pesan yang hendak disampaikan oleh penulis melalui media kata-kata atau bahasa tulis (Tarigan dalam Dalman, 2014).

Melalui pembelajaran bahasa indonesia siswa diharapkan terampil berbahasa serta mampu mengenali huruf, suku kata, kata, kalimat, serta mampu membaca dengan lancar, serta dihapkan mampu memahami teks pendek dengan lafal dan intonasi yang tepat (Hasraininur, 2015).

Tiga istilah sering digunakan untuk memberikan komponen dasar dari proses membaca, yakni recording, decoding, dan meaning. Rahim (2007) mengatakan bahwa proses recording dan decoding biasanya

\section{KAJIAN TEORETIS}

Menurut Darwadi (2002) membaca permulaan merupakan tahap awal dalam belajar membaca yang difokuskan kepada mengenal simbol-simbol atau tanda-tanda yang berkaitan dengan huruf-huruf sehinga menjadi pondasi agar anak dapat melanjutkan ketahap membaca permulaan. Kemampuan membaca yang diperoleh pada membaca permulaan akan sangat berpengaruh terhadap kemampuan membaca lanjut. Sebagai kemampuan yang mendasari kemampuan berikutnya, kemampuan membaca permulaan benar-benar memerlukan perhatian guru, sebab jika dari dasar tersebut tidak kuat, pada tahap membaca lanjut peserta didik akan mengalami kesulitan untuk dapat memiliki kemampuan membaca yang lebih baik, karena dengan membaca siswa akan dapat memperluas pengetahuan. Tujuan membaca menurut Tarigan (2005) adalah untuk mencari serta memperoleh informasi, mencakup isi, memahami makna bacaan. berlangsung pada kelas-kelas awal, yaitu SD kelas I, II, dan III yang dikenal dengan istilah membaca permulaan. Penekanan membaca pada tahap ini ialah proses perseptual, yaitu pengenalan korespondensi rangkaian huruf dengan bunyi-bunyi bahasa. Sementara itu proses meaning lebih ditekankan di kelas-kelas.

Berdasarkan latar belakang masalah yang telah diuraikan diatas, maka dirumuskan permasalahan sebagai berikut: (1) Apakah ada perbedaan pretest dan posttest dengan menerapkan metode struktural analitik sintetik (SAS) dalam membaca permulaan siswa kelas I SD?; (2) Apakah ada peningkatan pretest dan posttest dalam membaca permulaan siswa kelas I $\mathrm{SD}$ ?

Adapun tujuan penelitian berdasarkan rumusan masalah yang ada diatas adalah: (1) Untuk mengetahui perbedaan pretest dan posttest dengan menerapkan metode struktural analitik sintetik (SAS) dalam membaca permulaan siswa kelas I SD; (2) Untuk mengetahui peningkatan pretest dan posttest dalam membaca permulaan siswa kelas I SD.

Untuk dapat meningkatkan kemampuan membaca permulaan siswa Menurut Tim Pembna Bimbingan Teknis Calistung (dalam Meisal 2016) metode membaca Struktural Analitik Sintetik atau yang biasa disingkat dengan metode membaca SAS merupakan salah satu metode yang dapat digunakan dalam pembelajaran membaca permulaan. metode Struktural Analitik Sintetik (SAS) merupakan salah satu metode belajar yang cocok diterapkan pada saat pembelajaran membaca permulaan.

Metode Struktural Analitik Sintetik (SAS) adalah metode yang menampilkan kalimat utuh yang kemudian diurai hingga menjadi huruf dan dirangkai kembali hingga menjadi kalimat. Metode ini sejalan dengan prinsip linguistik yang memandang satuan bahasa terkecil yang bermakna untuk berkomunikasi. Dipilihnya metode SAS karena siswa mulai melafalkan huruf, suku kata, kata, dan kalimat sederhana 
dengan menggunakan vokal, lafal dan intonasi yang tepat (Mulyati, 2009).

Menurut Akhadiyah, dkk (1991) langkahlagkah metode Struktural Analitik Sintetik (SAS) ini dilaksanakan dalam dua periode yaitu periode membaca permulaan tanpa buku dan periode membaca permulaan dengan buku.

Adapun periode membaca permulaan tanpa buku, antara lain: 1) merekam bahasa anak; 2) bercerita dengan gambar; 3) membaca gambar; 4) membaca gambar dengan kartu kalimat; 5) proses struktural (s); 6) proses analitik (a); dan, 7) proses sintentik (s).

Kelebihan metode SAS menurut Kurniasih dan Sani (2016) yaitu: (1) Metode ini dapat sebagai landasan berfikir analisis; (2) Dengan langkah-langkah yang diatur sedemikian rupa membuat anak mudah mengikuti prosedur dan akan dapat cepat membaca pada kesempatan berikutnya; (3) Berdasarkan landasan linguistik metode ini akan menolong anak dalam menguasai bacaan dengan lancar. Metode yang dijelaskan diatas bukanlah metode yang terbaik sebab "tidak ada metode terbaik dan juga tidak ada metode terburuk". Setiap metode memiliki kelebihan dan kekurangan. Metode yang terbaik adalah metode yang cocok dengan peakaiannya, maksudnya yang sesuai dengan karakteristik dan kebutuhan siswa (Kurniaman, O 2016).

Kelemahan juga dipengaruhi oleh banyak hal seperti metode yang digunakan guru, kurangnya media, serta pemanfaatan yang tidak begitu maksimal digunakan untuk membaca. Dalam proses membaca permulaan, banyak yang dilakukan dengan berbagai cara. Ada yang menggunakan media, ada pula yang tidak menggunakan media untuk menyampaikan pesan. Siswa kelas rendah cenderung suka bermain. Jika diperhatikan siswa akan lebih tertarik jika di dalam pembelajarannya terdapat gambar (Wiyati, 2018).

\section{METODE PENELITIAN}

Jenis penelitian ini adalah penelitian kuantitatif dengan metode eksperimen dengan menggunakan desain penelitian one group pretest-posttest design yakni membandingkan nilai pretest dengan nilai posttest di dalam satu kelas. Pada desain ini, sebelum perlakuan yang

sebelum perlakuan diberikan terlebih dahulu tes awal (pretest), kemudian diberi perlakuan (treatment) dan selanjutnya diakhir pembelajaran diberi tes akhir (posttest) untuk lebih akurat membandingkan antara keadaan sebelum diberi perlakuan dengan sesudah (Sugiyono, 2017).

Tabel 1. Desain Penelitian

\begin{tabular}{ccc}
\hline $\begin{array}{r}\text { Tes awal } \\
\text { (Pretest) }\end{array}$ & Perlakuan & $\begin{array}{c}\text { Tes Akhir } \\
\text { (Posttest) }\end{array}$ \\
\hline $\mathrm{O}_{1}$ & $\mathrm{X}$ & $\mathrm{O}_{2}$ \\
\hline \multicolumn{2}{c}{ (Sumber: Sugiyono 2016) }
\end{tabular}

Subjek penelitian ini adalah siswa kelas I SDN 177 Pekanbaru yang berjumlah 34 orang. Subjek penelitian di dalam desain ini merupakan sampel yang menurut Donald Ary disebut sebagai "non independent sample" (Arikunto 2000).

Teknik pengumpulan data merupakan cara megumpulkan data yang dibutuhkan untuk menjawab rumusan masalah penelitian (Noor, Julansyah 2011). Teknik pengumpulan data dalam penelitian ini menggunakan teknik tes, dengan data yang dikumpulkan dalam penelitian ini diambil dari hasil pretest dan postest siswa, perbedaan skor pretest dan posttest siswa terhadap metode SAS dan peningkatan skor pretest dan posttest membaca permulaan siswa.

Untuk mengumpulkan data dalam penelitian ini, maka digunakan instrumen soal tes awal dan soal tes akhir yang terdiri dari lima kalimat sederhana yang disertai gambar, dimana soal pretes dan postes tersebut telah di uji validitasnya oleh ahli (expert judgment). Soal 
pretest dan posttest yang digunakan dalam penelitian ini adalah soal yang sama.

Teknik analisis data digunakan untuk menguji keberhasilan penelitian. Teknik analisis data yang digunakan dalam penilitian ini menggunakan rumus statistik sebagai berikut:

1. Skor hasil tes tiap siswa

Skor yang diperoleh siswa dari tes di konversikan dalam bentuk nilai dengan rentang 0 100 dengan menggunakan rumus:

Nilai Akhir $=\frac{\text { jumlah skor yang di peroleh siswa }}{\text { skor maksimun }} \times 100$, (Sudjana, 2005).

2. Menghitung rata-rata $(\overline{\mathrm{x}})$ skor hasil pretest dan posttest dengan rumus:

$\overline{\mathrm{x}}=\frac{\sum x i}{\mathrm{n}} \quad,($ Supardi, 2013)

3. Menghitung standar devisiasi (s) dengan rumus:

$s=\sqrt{\frac{\sum x i^{2}-\frac{\left(\sum x i\right) 2}{n}}{n-1}},($ Supardi, 2013)

4. Menghitung varians $\left(\mathrm{s}^{2}\right)$ dengan rumus:
$S^{2}=\frac{\sum x i^{2}-\frac{\left(\sum x i\right) 2}{n}}{n-1},($ Supardi, 2013)

5. Uji normalitas dengan menggunakan (kolmogorov smirnov)

6. Uji Homogenitas dengan rumus:

$F_{\text {hitung }}=\frac{\text { Varian Besar }}{\text { Varian Kecil }}$

(Sundayana, 2014)

7. Uji perbandingan (uji t) dengan rumus:

$t=\frac{M d}{\sqrt{\frac{\Sigma x_{d}^{2}}{n(n-1)}}}$, (Supardi, 2013)

8. Peningkatan kompetensi yang terjadi sebelum dan setelah pembelajaran dihitung dengan rumus gain ternormalisasi (normalized gain), yaitu:

$\mathrm{g}=\frac{\text { skor posttest-skor pretest }}{\text { skor ideal-skor pretest }}$

(Sundayana, 2014)

Kategori gain ternormalisasi (g) berpedoman pada standar dari Hake dalam Sundayana (2014) dapat dilihat pada tabel 2 dibawah ini:

Tabel 2. Kategori Gain Ternormalisasi

\begin{tabular}{cc}
\hline Nilai Gain Ternormalisasi & Interpretasi \\
\hline$-1,00 \leq \mathrm{g}<0,00$ & Terjadi penurunan \\
\hline $\mathrm{g}=0,00$ & Tidak terjadi penurunan \\
\hline $0,00<\mathrm{g}<0,30$ & Rendah \\
\hline $0,30 \leq \mathrm{g}<0,70$ & Sedang \\
\hline $0,70 \leq \mathrm{g} \leq 1,00$ & Tinggi \\
\hline
\end{tabular}

\section{HASIL DAN PEMBAHASAN}

\section{Data Pretest dan Posttest}

Hasil tes awal (pretest) adalah kemampuan membaca siswa SD, di mana siswa belum diberikan perlakuan dengan metode struktural analitik sintetik (SAS). Hasil test awal (pretest) dapat dilihat pada tabel 3 berikut:

Tabel 3. Data Hasil Kemampuan Membaca pada Tes Awal (Pretest)

\begin{tabular}{ccccccc}
\hline Data & $\begin{array}{c}\text { Jumlah } \\
\text { Siswa } \\
(\mathbf{n})\end{array}$ & $\begin{array}{c}\text { Rata-rata } \\
(\overline{\mathbf{x}})\end{array}$ & $\begin{array}{c}\text { Standar } \\
\text { Deviasi }(\mathbf{s})\end{array}$ & Varians $\left(\mathbf{s}^{2}\right)$ & $\begin{array}{c}\text { Nilai } \\
\text { Min }\end{array}$ & $\begin{array}{c}\text { Nilai } \\
\text { Max }\end{array}$ \\
\hline Pretest & 34 & 51.77 & 2.6678 & 7.1172 & 44.78 & 55.97 \\
\hline
\end{tabular}


Berdasarkan tabel 3 dapat diketahui bahwa rata-rata siswa sebelum tindakan adalah 51.77. Nilai maksimal adalah 55.97 dan nilai minimal adalah 44,78, serta Standar Deviasi 2.6778, Varians 7.1172. Sedangkan untuk data posttest dapat dilihat pada tabel 4 dibawah ini :

Tabel 4. Data Hasil Kemampuan Membaca pada Tes Akhir (Posttest)

\begin{tabular}{ccccccc}
\hline Data & $\begin{array}{c}\text { Jumlah } \\
\text { Siswa } \\
(\mathbf{n})\end{array}$ & $\begin{array}{c}\text { Rata-rata } \\
(\overline{\mathbf{x}})\end{array}$ & $\begin{array}{c}\text { Standar } \\
\text { Deviasi }(\mathbf{s})\end{array}$ & $\begin{array}{c}\text { Varians } \\
\left(\mathbf{s}^{\mathbf{2}}\right)\end{array}$ & Nilai Min & Nilai Max \\
\hline Posttest & 34 & 88.41 & 2.3697 & 5.6154 & 83.54 & 92.65 \\
\hline
\end{tabular}

Berdasarkan tabel 4 dapat diketahui bahwa rata-rata siswa setelah diberi perlakuan adalah 88,41. Nilai maksimal adalah 92.65 dan nilai minimal adalah adalah 83.54 , standar deviasi 2.3697 serta varians 5.6154 .

\section{Uji Normalitas Skor Pretest dan Posstest}

Uji normalitas data ini dilakukan dengan menggunakan Kolmogorov-Smirnov. Uji normalitas digunakan untuk mengetahui normalitas data skor tes awal dan data skor akhir dengan perumusan hipotesis sebagai berikut :

$\mathrm{H}_{0} \quad$ : data berdistribusi normal

$\mathrm{H}_{1} \quad$ : data tidak berdistribusi normal dengan kriteria pengujian :

Tolak $\mathrm{H}_{0} \mathrm{jika} \mathrm{a}_{\max }>\mathrm{D}_{\text {tabel }}$ dan

Terima $\mathrm{H}_{0} \mathrm{j}_{\mathrm{i}} \mathrm{ka} \mathrm{a}_{\max } \leq \mathrm{D}_{\text {tabel }}$

Pengujian hipotesis menggunakan taraf signifikan $\alpha=0.05$ dan $D_{\text {tabel }}=0.2332$ (dilihat pada tabel D untuk uji Kolmogorov-Smirnov sampel tunggal) dengan kriteria jika $a_{\max } \leq$ $\mathrm{D}_{\text {tabel }}$ maka $\mathrm{H}_{0}$ diterima dan disimpulkan bahwa data berdistribusi normal.

Adapun hasil perhitungan uji normalitas terhadap tes awal (pretest) dan tes akhir (posttest) dapat dilihat pada tabel 5 berikut:

Tabel 5. Hasil Uji Normalitas Pretest dan Posttest Kemampuan Membaca

\begin{tabular}{ccccc}
\hline \multirow{2}{*}{ Tes } & \multicolumn{3}{c}{ Normalitas } & \multirow{2}{*}{ Keputusan } \\
\cline { 2 - 4 } & $\mathbf{N}$ & $\mathbf{a}_{\text {maks }}$ & $\mathbf{D}_{\text {tabel }}$ & \\
\hline Awal (pretest) & 34 & 0.1166 & 0.2332 & Normal \\
Akhir (posttest) & 34 & 0.0508 & 0.2332 & Normal \\
\hline
\end{tabular}

Berdasarkan tabel 5 dapat diketahui bahwa skor awal (pretest) yaitu $\mathrm{a}_{\text {maks }}=0.1166$ dan $\mathrm{D}_{\text {tabel }}=0.1835$ maka $\mathrm{a}_{\text {maks }}<\mathrm{D}_{\text {tabel }}$ sehingga berdistribusi normal. Skor tes akhir (posttest) yaitu $\mathrm{a}_{\text {maks }}=0.0508$ dan $\mathrm{D}_{\text {tabel }}=$ 0.1835 maka $\mathrm{a}_{\text {maks }}<\mathrm{D}_{\text {tabel }}$ sehingga berdistribusi normal. Adapun Gain kemampuan membaca berjumlah 25.77 dengan rata-rata Gain sebesar 0.76. Gain kemampuan membaca siswa kelas I SD yang diperoleh sebesar 0.76 termasuk pada kategori tinggi.

\section{Uji Homogenitas Data}

Berdasarkan uji normalitas, diketahui tes awal, tes akhir, dan N-Gain berdistribusi normal, maka selanjutnya dapat dilakukan uji homogenitas. Pengujian homogenitas data ini dilakukan dengan teknik uji $\mathrm{F}$ (Fisher) dengan cara membandingkan varians data terbesar dan terkecil.

Perumusan hipotesis pengujian homogenitas sebagai berikut :

$\mathrm{H}_{\mathrm{o}}$ : Kedua varians homogen $\left(\mathrm{v}_{1}=\mathrm{v}_{2}\right)$

$\mathrm{H}_{\mathrm{a}}$ : Kedua varians tidak homogen $\left(\mathrm{v}_{1} \neq \mathrm{v}_{2}\right)$

Dengan taraf signifikan $\alpha=0,20 \quad F_{\text {hitung }}$ $=0.789$ dan $F_{\text {tabel }}=1.3442$ maka $F_{\text {hitung }}<F_{\text {tabel }}$ sehingga $\mathrm{H}_{\mathrm{o}}$ diterima berarti varians kedua data homogen. Dengan kriteria sebagai berikut:

Jika $F_{\text {hitung }}<F_{\text {tabel }}$, maka Ho diterima berarti varians homogen. 
Jika $F_{\text {hitung }}>F_{\text {tabel }}$, maka Ho ditolak berarti varians tidak homogen.

Tabel 6. Hasil Uji Homogenitas Kemampuan Membaca

\begin{tabular}{ccccc}
\hline \multirow{2}{*}{ Data } & \multicolumn{3}{c}{ Homogenitas } & \multirow{2}{*}{ Keputusan } \\
\cline { 2 - 4 } & Varians & $\boldsymbol{F}_{\text {hitung }}$ & $\boldsymbol{F}_{\text {tabel }}$ & \\
\hline Pretest & 7.1172 & 0.789 & 1.3442 & Homogen \\
Posttest & 5.6154 & & & Homogen \\
\hline
\end{tabular}

Berdasarkan tabel 6 dapat diketahui bahwa setelah setelah dilakukan uji homogenitas pada nilai tes awal dan tes akhir didapatkan $F_{\text {hitung }}<F_{\text {tabel }}$ atau $0.789<1.3442$. Hal ini berarti varians bersifat homogen atau dapat dilanjutkan dengan uji t.

\section{Uji t Pretest dan Posttest}

Berdasarkan uji normalitas terhadap nilai awal (pretest) dan nilai tes akhir (posttest) diperoleh bahwa kemampuan membaca siswa berdistribusi normal. Selanjutnya dilakukan uji t untuk mengetahui ada atau tidaknya perbedaan signifikan antara nilai rata-rata awal (pretest) dan nilai rata-rata akhir (posttest). Untuk menganalisis perbedaan antara nilai pretest dan posttest kemampuan membaca siswa menggunakan pretest dan posttest one grup design, maka dilakukan pengujian hipotesis komparasi dengan uji-t sebagai berikut :

$t=\frac{M d}{\sqrt{\frac{\Sigma x_{d}^{2}}{n(n-1)}}},($ Supardi, 2013)

dengan hipotesis sebagai berikut:

Tolak $\mathrm{H}_{0}$ jika $t_{\text {hitung }}>\mathrm{t}_{\text {tabel }}$ dan

Terima $\mathrm{H}_{0}$ jika $\mathrm{t}_{\text {hitung }}<\mathrm{t}_{\text {tabel }}$

Tabel 7. Uji t Skor Pretest Dan Posttest

\begin{tabular}{ccccccc}
\hline $\mathbf{N}$ & $\mathbf{M d}$ & $\mathbf{\Sigma} \mathbf{x d}^{\mathbf{2}}$ & $\mathbf{t}_{\text {tabel }}$ & thitung & Hipotesis & Kesimpulan \\
\hline 34 & 36.64 & 577.40 & 2.0345 & 51.080 & Tolak $\mathrm{H}_{\mathrm{o}}$ & Signifikan \\
\hline
\end{tabular}

Berdasarkan tabel 7 dapat dilihat bahwa $t_{\text {hitung }}=51.080$ dan $t_{\text {tabel }}=2.0345$ kemudian $t_{\text {hitung }}$ dibandingkan dengan $t_{\text {tabel }}$ dapat disimpulkan $t_{\text {hitung }}>\mathrm{t}_{\text {tabel}}$, yang berarti tolak $\mathrm{H}_{0}$ artinya signifikan.

\section{N-Gain}

Besarnya peningkatan membaca siswa sebelum dan setelah pembelajaran dihitung dengan rumus gain ternormalisasi (normalized gain). N-Gain bertujuan untuk mengetahui peningkatan kemampuan membaca sebelum dan sesudah perlakuan diberikan yaitu dengan penerapan metode struktural analitik sintetik (SAS). Adapun N-Gain kemampuan membaca berjumlah 25,77 dengan rata-rata $\mathrm{N}$-Gain sebesar 0.76 . Gain kemampuan membaca siswa kelas I SD yang diperoleh sebesar 0.76 termasuk pada kategori tinggi.

\section{Pembahasan}

Penelitian ini merupakan penelitian eksperimen dengan design One Group PretestPosttest Design, yaitu model penelitian ini memberikan perlakuan pada satu kelompok saja

tanpa kelompok pembanding. Di dalam desain ini, pengukuran dilakukan sebanyak 2 kali yaitu: sebelum eksperimen (pretest) dan sesudah eksperimen (posttest). Kesimpulannya siswa akan 
menjadi sampel dalam penelitian ini akan mendapatkan hak yang sama yaitu tes awal (pretest) dan tes akhir (posttest), perbedaannya pada saat tes awal siswa membaca menggunakan media kartu kalimat metode SAS tetapi belum diberikan perlakuan, sedangkan pada tes akhir siswa membaca menggunakan media kartu kalimat metode SAS.

Pembahasan terhadap hasil penelitian ini dibuat berdasarkan analisis data hasil tes awal (pretest), hasil tes akhir (posttest), peningkatan skor hasil kemampuan membaca siswa, dan besarnya pengaruh dalam penerapan metode struktural analitik sintetik (SAS) terhadap kemampuan membaca siswa kelas I.

Penilaian pada pretest, nilai siswa masih rendah, dimana rata-rata pada pretest sebesar 51.77 dengan skor pada tes awal (pretest) paling rendah sebesar 44.78 dan paling tinggi sebesar 55.97 sehingga perlu ditingkatkan. Pada pretest siswa belum mendapatkan perlakuan metode Struktural Analitik Sintetik (SAS). Pembelajaran membaca mempunyai peranan penting, sebab dengan membaca siswa mengembangkan nilainilai moral, kemampuan bernalar dan berkreativas (Retnaningrum, dkk, 2015). Oleh karena itu kemampuan membaca permulaan perlu diutamakan karena membawa pengaruh terhadap kemampuan membaca siswa selanjutnya. Kemampuan membaca permulaan merupakan suatu yang mendasari kemampuan membaca lanjut, maka kemampuan membaca permulaan perlu diperhatikan guru sebab jika dasar kemampuan tidak kuat, maka pada tahap selanjutnya siswa akan mengalami kesulitan untuk dapata memiliki kemampuan membaca yang memadai

Menurut Solchan, dkk (dalam Setyani, 2012) Pembelajaran membaca dengan menggunakan metode struktural analitik sintetik (SAS) dimulai dengan menampilkan struktur kalimat secara utuh. Sedangkan menurut Wahyuni (2010) metode struktural analitik sintetik (SAS) memulai pembelajaran membaca permulaan dari wacana utuh kemudian ke unsurunsur yang lebih kecil.

1. Kemampuan membaca permulaan siswa kelas I sebelum diberi perlakuan (pretest)
Kegiatan posttest ini dilakukan pada tanggal 4 Februari 2019, tujuannya untuk mengetahui kemampuan awal yang dimiliki anak pada saat membaca. Hasil penelitian dapat diketahui bahwa perolehan nilai rata-rata kemampuan siswa dikelas sebelum diberi perlakuan dengan penerapan metode SAS adalah 51.77 yang dianggap bagi peneliti masih rendah yang berarti hasil peroleh nilai siswa dalam membaca belum memuaskan dan masih perlu mendapatkan perlakuan. Hal ini disebabkan oleh metode belajar yang diterapkan guru selama ini monoton dan dianggap kurang menarik bagi siswa kelas I.

Sebelum pretest dilakukan anak dikondisikan terlebih dahulu untuk duduk dengan tenang, dan peneliti akan memanggil satu persatu nama siswa sesuai urutan di absen untuk maju kedepan kelas lalu membaca dalam media kartu kalimat sesuai penerapan metode SAS tanpa memberi tau langkah kerja/ cara membacanya.

Selama tes membaca teks bacaan anak cendrung salah membaca huruf dan masih mengeja setiap kata dan cenderung mengalami kesulitan saat membaca konsonan rangkap. Untuk mengatasi permasalahan tersebut diperlukan ada nya metode SAS dengan bantuan kartu kalimat yang terdapat gambar didalamnya.

2. Kemampuan membaca permulaan siswa kelas I setelah diberi perlakuan (posttest)

Kegiatan posttest ini dilakukan pada tanggal 19 Februari 2019, penggunaan metode SAS pada kemampuan membaca permulaan kelas I diperoleh nilai rata-rata kemampuan siswa dari 51.77 menjadi 88,41 dengan standar deviasi 2.3697 yang dianggap sudah sangat baik. Perolehan nilai rata-rata pada pada saat diterapkannya penggunaan metode SAS terhadap kemampuan membaca mengalami peningkatan dibandingkan sebelum diterapkannya metode SAS, dimana perolehan nilai rata-rata posttest lebih tinggi dibandingkan nilai rata-rata pretest.

Berdasarkan perbedaan rata-rata tes awal (pretest) dengan tes akhir (posttest) tersebut dapat dilihat bahwa terdapat perbedaan peningkatan kemampuan membaca siswa dengan penerapan metode struktural analitik sintetik (SAS) sebesar 36.64, perbedaan ini didasarkan pada hasil uji t. 
Diperoleh $t_{\text {hitung }}>t_{\text {tabel }}$ atau $51.080>$ 1.3077. Hal ini menunjukkan bahwa $\mathrm{H}_{\mathrm{o}}$ ditolak berarti terdapat perbedaan peningkatan kemampuan membaca siswa yang signifikan antara hasil pretest dan posttest peningkatan kemampuan membaca ini dikarenakan dengan penerapan metode SAS. Setelah dilakukan pretest dan posttest, untuk mengetahui peningkatan nilai kemampuan membaca siswa maka dilakukan analisis peningkatan nilai sebelum dan sesudah perlakuan yang dihitung dengan uji gain ternormalisasi. Dari analisis terhadap nilai gain ternormalisasi memiliki rata-rata 0.76 dengan kategori tinggi dengan standar deviasi 0.0558 .

Berdasarkan uraian tersebut dapat diperoleh kesimpulan bahwa terjadi perbedaan dalam pretest maupun posttest dan juga terdapat

\section{SIMPULAN DAN REKOMENDASI}

Berdasarkan hasil analisis dan pembahasan yang telah dilaksanakan disimpulkan bahwa penerapan metode struktural analitik sintetik (SAS) dapat meningkatkan membaca permulaan siswa kelas I SD. Hal ini dapat dilihat dari data yang diperoleh dalam penelitian. Perbedaan ini didasarkan pada hasil uji t. di peroleh $t_{\text {hitung }}$ memenuhi kriteria $t_{\text {hitung }}>t_{\text {tabel }}$ atau 51,080 atau 2,0345. Dengan rata-rata N-Gain sebesar 0,76 termasuk pada kategori tinggi, dengan hal ini menunjukan Ho ditolak dan $\mathrm{Ha}$ diterima berarti terdapat perbedaan dan

\section{DAFTAR PUSTAKA}

Akhadiah, S. dkk. (1991). Bahasa Indonesia I. Departemen Pendidikan dan Kebudayaan Direktorat Jenderal Pendidikan Tinggi Proyek Pembinaan Tenaga Kependidikan.

Arikunto, S. (2012). Prosedur Pendidikan Suatu Pendekatan Praktek. Jakarta: Rhineka Cipta.

Dalman. (2014). Keterampilan Membaca. Jakarta: Raja Grafindo Persada.

Darwadi. 2002. Langkah-Langkah Keterampilan Proses. Jakarta: Gramedia.

Hasraininur. (2015). Penerapan Metode Struktural Analisis Sintetis (SAS) Untuk Meningkatkan Kemampuan Membaca peningkatan dalam pretest dan posttest tersebut, dengan begitu metode SAS dapat membuat siswa lebih mudah dan lebih menarik dengan apa yang mereka lihat dalam media tersebut karna terdapat terdapat bacaan serta gambar ataupun juga warna yang cerah bagi siswa kelas I. Hal ini sejalan dengan Meisal, Ulil (2016) bahwa dengan menggunakan metode SAS berpengaruh sangat kuat dalam meningkatkan kemampuan membaca permulaan siswa, selain itu metode SAS mampu mengubah pembelajaran biasa yang selama ini berpusat pada guru menjadi pembelajaran yang lebih baik menitik beratkan pada keaktifan siswa dan meningkatkan daya tangkap siswa serta memotivasi siswa yang malas membaca karena pembelajaran dibantu dengan media.

peningkatan membaca siswa dengan menerapkan metode struktural analitik sintetik (SAS).

Berdasarkan simpulan dari hasil penelitian maka peneliti merekomendasikan beberapa hal, yaitu: 1) Guru dapat menerapkan metode Struktural Analitik Sintetik (SAS) dalam penerapan kemampuan membaca permulaan pada siswa kelas I; 2) Hasil penelitian ini dapat dijadikan sebagai referensi dalam memberikan informasi tentang pelaksanaan pembelajaran membaca dengan menerapkan metode Struktural Analitik Sintetik (SAS).

Permulaan pada Siswa Kelas I D SD Negeri 184 Pekanbaru. Jurnal Online Mahasiswa Pendidikan Guru Sekolah Dasar. FKIP Universitas Riau (Online). diakses 20 April 2019

https://jom.unri.ac.id/index.php/JOMFKIP/ article/view/361.

Kurniasih, I \& Sani, B. (2016). Ragam Pengembangan Model Pembelajaran. Jakarta: Kata Pena.

Kurniaman, O \& Noviana, E. (2016). Metode Membaca SAS (Struktural Analitik Sintetik) dalam Meningkatkan Keterampilan Membaca Permulaan di 
Kelas I SDN 79 Pekanbaru. Primary: Jurnal Pendidikan Guru Sekolah Dasar. $5(2)$. 149-157. https://ejournal.unri.ac.id/index.php/JPFKI P/article/view/3705

Meisal, U. dkk. (2015). Pengaruh Metode Struktural Analitik Sintetik (SAS) Terhadap Kemampuan Membaca Permulaan Siswa Kelas I SD Negeri 79 Pekanbaru. Jurnal online Mahasiswa Pendidikan Guru Sekolah Dasar. FKIP Universitas Riau. Pekanbaru (Online). diakses 26 April 2019. https://jom.unri.ac.id/index.php/JOMFKIP/ article/view/12004/0

Mulyati, Y. (2009). Keterampilan Berbahasa Indonesia. Jakarta: Universitas Terbuka.

Rahim, F. (2007). Pengajaran Membaca di Sekolah Dasar. Jakarta: PT Bumi Aksara.

Retnaningrum, S.D., dkk. (2015). Pembelajaran Kesadaran Fonemik dengan Menggunakan Metode Struktural Analisis Sintetis (SAS) Untuk Meningkatkan Kemampuan Membaca Permulaan Siswa Kelas Satu Sekolah Dasar. Jurnal Kajian Ilmiah Psikologi (Online). diakses 27 April 2019. http://journal.unika.ac.id/index.php/pre/arti cle /view/509
Sundayana, R. (2014). Statistika Penelitian Pendidikan. Bandung: Alfabeta.

Sudjana. (2005). Metode Statistika. Bandung: Tarsito.

Sugiyono. (2012). Metode Penelitian Pendidikan. Bandung: Alfabeta

Sugiyono. (2016). Metode Penelitian Kuantitatif, Kualitatif dan $R \& D$. Bandung: PT. Alfabeta.

Supardi. (2013). Aplikasi Statistika dalam Penelitian Edisi Revisi. Jakarta: Change Publication

Tarigan, H.G. (2008). Membaca sebagai Suatu Keterampilan Berbahasa. Bandung: Angkasa.

Wahyuni, S. (2010). Cepat Bisa Membaca. Jakarta: PT. Gramedia.

Wiyati. (2018). Penerapan Model Pembelajaran Picture and Picture Untuk Meningkatkan Kemampuan Membaca Permulaan Siswa Kelas I Sekolah Dasar. Primary: Jurnal Pendidikan Guru Sekolah Dasar. 7(1). 113.https://ejournal.unri.ac.id/index.php/JPF KIP/article/view/5357/5024, diakses 28 April 2019. 